\title{
Molecular modeling studies of repandusinic acid as potent small molecule for hepatitis B virus through molecular docking and ADME analysis
}

\author{
Vijayakumar Subramaniyan*, Reetha Sekar, Arulmozhi Praveenkumar, Rajalakshmi Selvam \\ Computational Phytochemistry Lab, PG and Research Department of Botany and Microbiology AVVM Sri Pushpam College \\ (Autonomous), Tamil Nadu, 613503, India \\ *Correspondence: svijaya_kumar2579@rediff.com
}

Received April 5, 2019; Revised June 26, 2019; Accepted July 12, 2019

\begin{abstract}
Background: Hepatitis B virus (HBV) has affected over 300 million people worldwide which causes to induce mostly liver disease and liver cancer. It is a member of the family Hepadnaviridae which is a small DNA virus with unusual characters like retroviruses. Generally, hepatoprotective drugs provoke some side effects in human beings. For the reason, this study aims to identify alternative drug molecules from the natural source of medicinal plants with smaller quantity of side effects than those conventional drugs in treating $\mathrm{HBV}$.

Methods: We developed computational methods for calculating drug and target binding resemblance using the Maestro v10.2 of Schrodinger suite. The target and ligand molecules were obtained from recognized databases. Ligand molecules of 40 phytoconstituents were retrieved from variety of plants after we executed crucial analyses such as molecular docking and absorption, distribution, metabolism, and excretion (ADME) analysis.

Results: In the docking analysis, the natural analogues repandusinic acid showed better docking scores of -14.768 with good binding contacts. The remaining bioactive molecules corilagin, furosin, nirurin, iso-quercetin and gallocatechin also showed better docking scores.

Conclusion: This computational analysis reveals that repandusinic acid is a suitable drug candidate for HBV. Therefore, we recommend that this analogue is suitable in further exploration using in vitro studies.
\end{abstract}

Keywords: hepatitis B virus; phytoconstituents; molecular docking; ADMET analysis

\begin{abstract}
Author summary: Hepatitis B virus affects the human beings due to the virus replication. The conventional drugs of hepatitis B virus have side effects on human and few are not responsible for that diseases complication. Hence, present computational studies found a few effective phytocompounds for hepatitis B virus which are identified based on their mode of interactions with hepatitis B viral protein molecule. Among the molecules, repandusinic acid has a better docking score and it was shown good binding affinities with the target. In vitro and in vivo evaluation will be essential and we hope this study will be helpful to proceed further with the effective drug development.
\end{abstract}

\section{INTRODUCTION}

According to world health organization (WHO), two billion people have been infected with hepatitis $B$ virus (HBV) globally, and more than 400 million people are affected as lifetime patients [1]. Owing to severe consequences of hepatitis the people are mostly affected by liver failure, fibrosis, cirrhosis and hepatocellular carcinoma (HCC). Whereas in India, approximately 80 million people are affected and 2,400,000 people died due to this disease complications [2].

Recently, the US Food and Drug Administration (FDA) 
have approved seven drugs for the treatment of HBV. Of them, alpha-interferon and ribavirin are used together for reducing the affection of Hepatitis B virus. But, these two drugs cause several side effects like hemolytic anemia, renal failure, etc [3]. The remaining hepatitis drugs of lamivudine (3TC), adefovir dipivoxil (ADV), entecavir (ETV), telbivudine (TBH) and tenofovir-DF (TDF) would cause the extensive ranges of disadvantages on human beings after the consumption [4,5]. Therefore, the new strategies of potential anti-HBV drug are still needed. Accordingly, this research depends on natural sources for identifying novel drug to HBV.

Nature is the source of medicinal agents since time immemorial. Recently, the people are depending on treatment based on plant because of their fewer side effects. Currently, many bioactive molecules have been isolated from the medicinal plants and those are used by human beings for the purpose of making their life healthy. These bioactive compounds were isolated by various researchers, but it is needed to know about their molecular interactions. Nowadays, molecular docking mechanisms are adopted for model drug design to understand the drug and receptor binding interactions. The technology can help to design novel drug component. Therefore, the aim of the present study is to screen better drug candidate to inhibit the HBV complications through molecular docking.

\section{RESULTS AND DISCUSSION}

\section{Crystal structure of Hepatitis B virus $X$ protein (HBx)}

Hepatitis B virus $\mathrm{X}$ protein ( $\mathrm{HBx}$ ) is a tiny authoritarian protein molecule that is conserved in mammalian hepadnaviruses [6]. Similar to $\mathrm{HBx}$, the woodchuck hepatitis virus $\mathrm{X}$ protein (WHx) causes the viral infections to human beings and also binds DDB1 [7]. Bergametti et $a l$. [8] have reported a partially conserved sequence motif in $\mathrm{HBx}$ and WHx that is essential to DDB1 involvements.

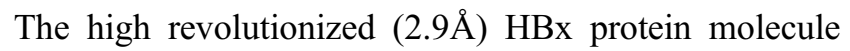
was used for this molecular docking analysis with phytoconstituents.

\section{Binding site analysis}

In this study, the site analysis has shown five major active drugable binding sites from target molecule. Among the five sites, site 1 has been chosen for further study based on their site map score and volume of the area. The site map showed their binding cavity residues were TYR171, ALA221, ILE220, LYS168, TYR271, MET218, GLU65, ILE124, ILE123, VAL63, MET64, GLY122, ILE121, ILE120, GLY119, THR118, GLU312, ASN16, CYS313,
GLY17, LEU314, CYS18, VAL19, THR315, CYS260, HIS261, ASN262, ARG263, PRO223 and VAL222 (Figure 1). Likewise, Iftikhar et al. [9] have examined the ligand binding site from 4-aminobutyrate aminotransferase for docking with known analogues. Lots of computational studies have been not only applied to this research but also that carried out this binding site analysis techniques in various target molecules. Our previous research has found the active binding cavity in the target of PPAR $\gamma$ [10-12]. As a result of this analysis, the qualified binding site was taken for grid generation, which fix the drugable binding site on target [13].

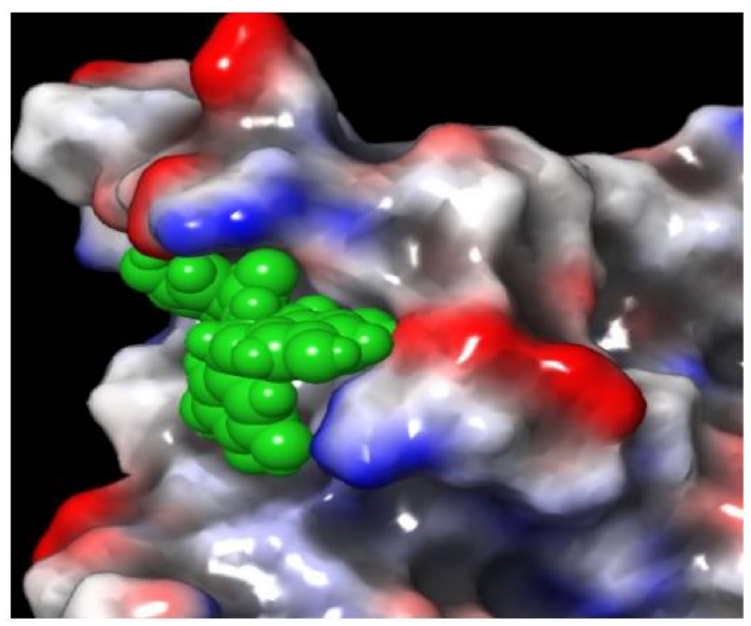

Figure 1. Ligand active binding cavity HBx.

\section{Molecular docking}

The molecular docking was carried out in the molecule of hepatitis B virus $\mathrm{X}$ protein $(\mathrm{HBx})$ with experimentally reported and known phytoconstituents of medicinal plants. Among them, repandusinic acid is positioned superior docking score, with compared to other ligand molecules (Table 1). It also shows better binding affinities with a protein molecule. Among the 40 bioactive molecules, the repandusinic acid had a better docking score of -16.768 followed by corilagin, furosin, nirurin, iso-quercetin and gallocatechin were also shown favorable docking scores of this study (Table 1). Through molecular docking we found that six bioactive molecules from the ligands have received the encouraging docking score with the target of human hepatitis B viral capsid. In this analysis, most of the molecules have exhibited excellent docking scores with the receptor molecule, which begins with the docking scores of -8.07 . Recently, lots of computational approach has been developed to find the effective drug molecules against worldwide challenging diseases and disease-causing organisms [14]. The 
Table 1 Docking results of 40 natural compounds from medicinal plant sources

\begin{tabular}{|c|c|c|c|c|c|}
\hline No. & Compound names & Name of the plant & Number of residues interactions & $\begin{array}{l}\text { Glide docking } \\
\text { XP score }\end{array}$ & $\begin{array}{l}\text { Glide e-model } \\
\text { (kcal/mol) }\end{array}$ \\
\hline 1 & Repandusinic acid & Phyllanthus niruri $\mathrm{L}$. & $\begin{array}{l}\text { Asn16, Glu312, Arg263, Lys168, } \\
\text { Glu65, Ala62, Thr118 }\end{array}$ & -16.180 & -125.993 \\
\hline 2 & Corilagin & $\begin{array}{l}\text { Phyllanthus niruri } \mathrm{L} \text {. } \\
\text { Phyllanthus emblica } \mathrm{L} \text {. }\end{array}$ & $\begin{array}{l}\text { His } 261, \operatorname{Arg} 263, \text { Ala221, Cys } 18, \\
\text { Lys168, Gly122 }\end{array}$ & -13.399 & -92.836 \\
\hline 3 & Furosin & Phyllanthus niruri $\mathrm{L}$. & $\begin{array}{l}\text { Glu312, Cys18, Asn262, Arg263, } \\
\text { Lys168 (salt bridge) }\end{array}$ & -13.454 & -98.141 \\
\hline 4 & Nirurin & Phyllanthus niruri $\mathrm{L}$. & $\begin{array}{l}\text { Asn262, His261, Cys18, Thr118, } \\
\text { Glu65, Tyr171 }\end{array}$ & -12.392 & -79.381 \\
\hline 5 & Iso-quercitin & Hemidesmus indicus $\mathrm{L}$. & $\begin{array}{l}\text { Cys18, Ile124, Glu65, Ala221, Arg263, } \\
\text { His261 (salt bridge) }\end{array}$ & -12.299 & -86.492 \\
\hline 6 & Rutin & $\begin{array}{l}\text { Phyllanthus niruri } \mathrm{L} . \\
\text { Delonix elata } \mathrm{L} .\end{array}$ & $\begin{array}{l}\text { Glu65, Ile124, Cys18, Thr20, Ala221, } \\
\text { Arg263, His261(salt bridge) }\end{array}$ & -11.848 & -88.335 \\
\hline 7 & $(+)$ Gallocatechin & Phyllanthus niruri $\mathrm{L}$. & His261, Thr118, Lys168, Asn16 & -11.216 & -95.126 \\
\hline 8 & Hesperidin & Citrus sp. L. & Ala221, Cys18, Thr20, Arg263, Leu66 & -10.247 & -115.29 \\
\hline 9 & Quercitrin & $\begin{array}{l}\text { Phyllanthus niruri } \mathrm{L} \text {. } \\
\text { Acalypha indica } \mathrm{L} \text {. }\end{array}$ & $\begin{array}{l}\text { Leu314, Tyr171, Glu65, Ala262, rg263, } \\
\text { His261(salt bridge) }\end{array}$ & -10.009 & -105.236 \\
\hline 10 & Astragalin & Phyllanthus niruri $\mathrm{L}$. & $\begin{array}{l}\text { Ala221, Lys168, Arg263, Arg262, } \\
\text { Glu65, Cys18 }\end{array}$ & -9.503 & -94.263 \\
\hline 11 & Geranin & Phyllanthus niruri $\mathrm{L}$. & $\begin{array}{l}\text { Arg263, His22, Thr20, Arg68, Leu66, } \\
\text { Glu65, Cys18 }\end{array}$ & -9.221 & -97.741 \\
\hline 12 & Fisetin & Mangifera indica $\mathrm{L}$. & Arg263, Ala221, Glu65, Cys 18 & -8.870 & -82.586 \\
\hline 13 & Myricetin & $\begin{array}{l}\text { Holigarna grahamii (Wight) } \\
\text { Kurz. }\end{array}$ & Leu314, Glu65, Lys168, Glu65 & -8.346 & -82.077 \\
\hline 14 & Ascorbic acid & Nervilia aragona $\mathrm{L}$. & $\begin{array}{l}\text { Arg263, Tyr271, Ala221, Lys168, } \\
\text { His261, Asn262 }\end{array}$ & -8.304 & -84.664 \\
\hline 15 & Astragalin & Cuscuta chinensis $\mathrm{L}$. & $\begin{array}{l}\text { Leu66, Glu65, Ile124, Asn262, Phe169, } \\
\text { Lys168 }\end{array}$ & -8.254 & -92.314 \\
\hline 16 & Kaempferol & $\begin{array}{l}\text { Jatropha curcas, Phyllathus } \\
\text { niruri L. }\end{array}$ & $\begin{array}{l}\text { Arg263, Ala221, Lys168, Glu168, } \\
\text { Glu65, Leu314 }\end{array}$ & -8.109 & -98.9 \\
\hline 17 & Gallic acid & $\begin{array}{l}\text { Phyllathus niruri } \mathrm{L} \text {. } \\
\text { Aerva lanata } \mathrm{L} \text {. }\end{array}$ & Arg263, Ala221, Lys168 & -7.943 & -97.417 \\
\hline 18 & Tartaric acid & Gisekia phannaceides & Arg263, Tyr271, His261, Lys168 & -7.652 & -75.934 \\
\hline 19 & Nirphyllin & Phyllathus niruri L. & His261, Cys18, Gly122 & -7.570 & -90.786 \\
\hline 20 & Quinic acid & $\begin{array}{l}\text { Holigarna grahamii (Wight) } \\
\text { Kurz. }\end{array}$ & Asn16, Met66, Ile61 & -7.481 & -80.054 \\
\hline 21 & Chlorogenic acid & Eryngium planum $\mathrm{L}$. & Asn262, Arg263, Tyr 271, Ile124 & -7.238 & -78.122 \\
\hline 22 & Caffeic acid & Convolvulus gangeticus & Arg263, Tyr271, Ile124 & -7.143 & -63.632 \\
\hline 23 & Isovitexin & $\begin{array}{l}\text { Jatropha mollissima (pohl) } \\
\text { baill }\end{array}$ & $\begin{array}{l}\text { Glu312, Asn16, His261, } \operatorname{Arg} 263, \\
\text { Ala221 }\end{array}$ & -7.006 & -68.914 \\
\hline 24 & (-) Epicatechin & Camellia sinensis $\mathrm{L}$. & $\begin{array}{l}\text { Thr20, Glu65, Lys168, Ala221, } \\
\text { Arg263, His } 261\end{array}$ & -6.980 & -91.758 \\
\hline 25 & $(+)$ Catechin & $\begin{array}{l}\text { Camellia sinensis L. } \\
\text { Albizia lebbeck L. }\end{array}$ & His261, Leu314, Glu65, Met64, Ile61 & -6.650 & -72.007 \\
\hline 26 & Eriodictyol & $\begin{array}{l}\text { Lyonia ovalifolia } \mathrm{L} . \\
\text { Lythrum salicaria } \mathrm{L} \text {. }\end{array}$ & $\begin{array}{l}\text { Thyr20, Thr315, His261, Arg263, } \\
\text { Ala221 }\end{array}$ & -6.531 & -85.558 \\
\hline 27 & Ferulic acid & Beta vulgaris $\mathrm{L}$. & Tyr271, Arg263, Ile124 & -6.428 & -81.391 \\
\hline 28 & Shikonin & $\begin{array}{l}\text { Lithospermum erythrorhizon } \\
\text { Siebold \& Zucc }\end{array}$ & Aerg263, Phe169, Ile124 & -6.221 & -86.663 \\
\hline 29 & Venellic acid & Capparis zeylanica $\mathrm{L}$. & Asn262, Arg263, Tyr271, Lys168 & -6.118 & -70.845 \\
\hline
\end{tabular}


Repandusinic acid as potent small molecule for hepatitis B virus

\begin{tabular}{|c|c|c|c|c|c|}
\hline No. & Compound names & Name of the plant & Number of residues interactions & $\begin{array}{l}\text { Glide docking } \\
\text { XP score }\end{array}$ & $\begin{array}{l}\text { Glide e-model } \\
(\mathrm{kcal} / \mathrm{mol})\end{array}$ \\
\hline 30 & Estrodiol & Momordica charantia $\mathrm{L}$. & Arg263, Phe169, Ile124 & -6.007 & -69.064 \\
\hline 31 & Taraxacin & Calotropis procera & Tyr271, Arg263, Ile124 & -5.743 & -37.129 \\
\hline 32 & Brevifoin & Phyllathus sps. & Arg263, Ala221, Lys168 & -5.520 & -65.546 \\
\hline 33 & Phyltetralin & Pilates niruri $\mathrm{L}$. & Cys 18 & -5.517 & -58.561 \\
\hline 34 & (-) Limonine & Limonia acidissima $\mathrm{L}$. & $\begin{array}{l}\text { Cys18 } \\
\text { Thr20, Leu314, Gly122 }\end{array}$ & -5.481 & -69.007 \\
\hline 35 & Hypophyllanthin & $\begin{array}{l}\text { Phyllathus niruri } \mathrm{L} . \\
\text { Phyllathus amarus } \mathrm{L} \text {. }\end{array}$ & Arg263, Asn262, Lys168, Ile124 & -5.372 & -71.809 \\
\hline 36 & Taraxastrol & Calotropis procora & Ile165 & -5.204 & -57.032 \\
\hline 37 & Niranthin & Phyllathus niruri L. & Thr20, Cys18, His 261 & -5.029 & -54.594 \\
\hline 38 & Salycilic acid & Filipendula ulmoria $\mathrm{L}$. & Lys168, Ile124 & -4.858 & -73.773 \\
\hline 39 & Linolenic acid & Nervilia aragona $\mathrm{L}$. & Tyr271, Arg263 & -4.629 & -76.13 \\
\hline 40 & Tridecanol & Nervilia aragona $\mathrm{L}$. & Tyr271, Ala221 & -4.568 & -51.578 \\
\hline
\end{tabular}

computational analysis provide us various essential particulars like docking score, binding energy, binding affinities and also show the ligand potentiality. Generally, the binding affinities were shown predominantly the ligand involvement and its flexibility with the protein cavity residues. In this complex structure, we identified such kinds of docking parameters and binding affinities that contact with ligands to target, which are essentially occupied in the hydrogen bond side chain, back bone and $\pi-\pi$ stacking contacts.

\section{Repandusinic acid}

The small molecule of repandusinic acid had the effective docking scores of -14.768 and docking parameters such as ligand docking scores. The energy values were displayed in Table 1 . It has revealed well countable binding affinities with the residues of human hepatitis B viral protein. Here, many binding contacts were involved with target residues. Some of the interactions depend on both specific interactions with the ligand binding site and non-specific forces to the outside of the target binding cavity. Various kinds of binding affinities contributed to ligand and target. Exactly, hydrogen bond side chain, back chain and Pi-Pi stacking contacts were occupied between both molecules. After careful examination of the ligand and protein complexes, their contact arrangement was found. The complex displayed nine binding contacts between those two molecules (target to ligand). The residues GLU65, ALA62, THR118, GLU312, ASN16, LEU314, ARG63, ALA221 and LYS168 contacts with repandusinic acid which are displayed with their hydrogen distances in Figure 2. From this observation, we found ARG63 covalently binds with that of small molecule which connects back bone and salt bridge contacts. Among the residues contacts, eight residues
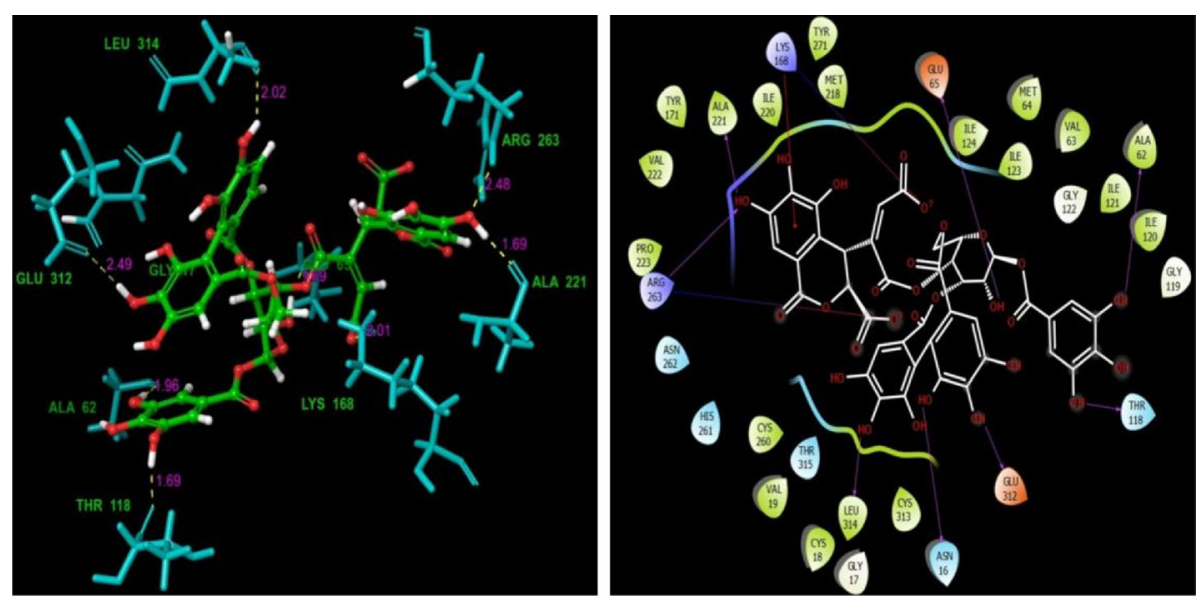

Figure 2. Residues and hydrogen bond contacts (yellow dotted line) with their distance values (pink) in repandusinic acid, and the 2D template representing the types of contacts involved between the ligand and target. 
contacts belong to hydrogen bond back bone such as GLU65, ALA62, THR118, GLU312, ASN16, LEU314 and ALA221, which are all binds with ligand hydroxyl groups $(\mathrm{OH})$ (Figure 2). LYS168 also connects a salt bridge and hydration site contacts with ligand oxygen groups. Here, the hydrogen bond side chain is indicated by the dotted blue straight line. The hydrogen bond back bone is indicated by solid blue straight line. And, the dumbbell shaped like a green color line indicated the Pi-Pi stacking contact. The red line indicated the hydration site contact. The repandunic acid is an alkaloids nature of the phytoconstituent which are available in Phyllanthus amarus medicinal plant. It is was confirmed to wide range of bio potential for many disease complications, which includes radical scavenging activity and can be a drug for Anti viral activity especially Virus like HIV-1 (protease) (Raintree Nutrition, Inc. Carson City, Nevada 89701, 2004).

\section{Corilagin}

Among the 40 small molecules, corilagin had the next docking scores of this study $(-12.921)$ (Table 1). Examination of the docked revealed that the residue contacts include CYS18, LYS168, GLY122, VAL259, HIS261, ARG263 and ALA221. Figure 3 shows the residue contacts in dotted yellow and their distance values that were represented in pink. The hydrogen bond distance values were 1.92 (VAL259), 2.52 (CYS18), 1.98 (HIS261), 2.78 (ARG263), 1.86 and 1.95 (ALA221), 2.34 (LYS168) and 1.69 and 1.84 (GLY122), respectively. In interaction map, all the residues were involved in formation of hydrogen bond back bone contacts with ligand. Specifically, the residue LYS168 was formed of both hydrogen and hydration site contacts with ligand oxygen groups. While, the residue ARG263 was involved in hydrogen back chain contacts and hydration site with ligand hydroxyl group. Surprisingly, the residue GLY122 is involved in covalent hydrogen bond back bone formation with corilagin. Corilagin is one of the important phytpconstituent in Phyllanthus niruri [16]. It is present in the nature of the ellagitanin. This molecule can also be found in other plants such as Alchornea glandulosa, Caesalpinia coriaria and Punica granatum. The extensive pharmacological activities of corilagin have been articulated, such as anti-atherogenic, anti-oxidant, hepatoprotective, and anti-tumor [17-20]. This shows the favorable docking score with the human hepatitis B viral protein (HBx) molecule (Table 2).

\section{Furosin}

Furosin had the third valuable docking score -12.58 (Table 1). Investigation of the docked complex demonstrates that the contacts include LYS168, GLY122, ALA62, GLU312, CYS18, ASN262, HIS261 and ARG263. In the molecular structure, the residues has shown that their contacts distance values were 2.18 (LYS168), and covalent contacts were 1.87 and 1.80 , $1.93,2.11,1.82,2.23$ and 1.69 , respectively. The residue contacts and their distance values were highlighted in pink color in Figure 4. From this interaction map, we found that the residues contacts with various atoms of the ligand molecule. Of them, the residues LYS168 and ASN262 were both involved in hydrogen bond back bone formations with the oxygen groups of furosin. Also, the residues GLY122, ALA62, GLU312, CYS18 and HIS261 were all involved in hydrogen bond back bone contacts with the hydroxyl groups of small molecule. But the residue ARG263 binds with ligand by the arrangement of salt bridge. Figure 4 has shown their binding contact types. Previously, the bioactive molecule of furosin were reported in various medicinal plants such as Phyllanthus emblica, $P$. virgatus, $P$. sellowianus and $P$. debilis. These plants have diverse biological activities including antioxidant, anti-hyperalgesic and wound healing [21-25]. Nevertheless, this molecular docking approach has presented their potentials against the hepatitis B virus.
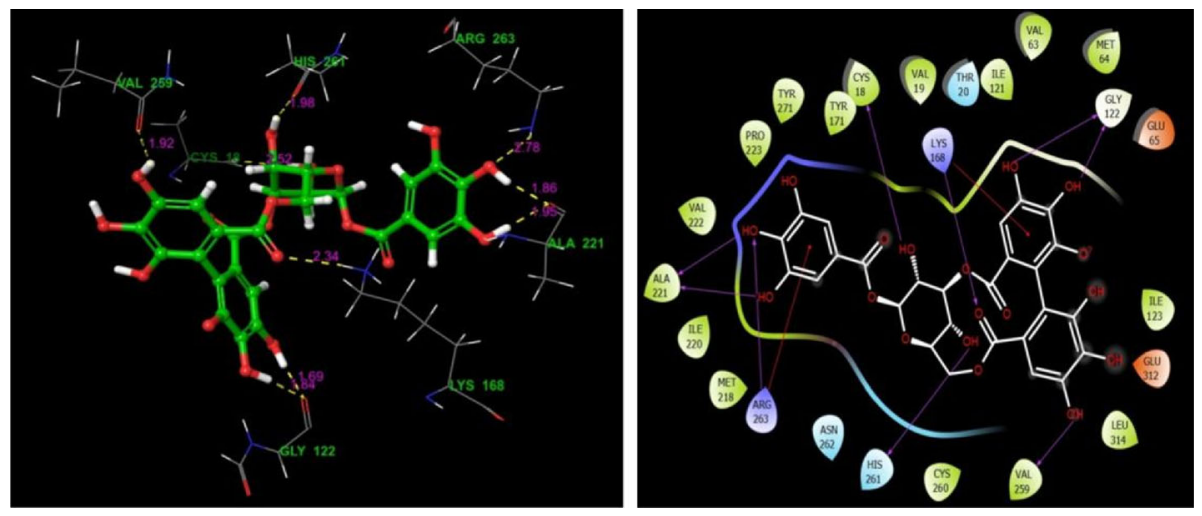

Figure 3. Residues and hydrogen bond contacts (yellow dotted line) with their distance values (pink) in corilagin, and the 2D template representing the types of contacts involved between the ligand target. 
Table 2 Physicochemical properties and biological functions of the 40 bioactive molecules analyzed by using QuikProp

\begin{tabular}{|c|c|c|c|c|c|c|c|c|c|c|}
\hline $\begin{array}{c}\text { No. Molecular } \\
\text { formula }\end{array}$ & $\begin{array}{c}\text { Molecular } \\
\text { weight } \\
(\mathrm{g} / \mathrm{mol})\end{array}$ & Volume & SASA & $\begin{array}{c}\text { Acceptor } \\
\text { H bond } \\
\text { groups }\end{array}$ & $\begin{array}{l}\text { Donor } \\
\mathrm{H} \text { bond } \\
\text { groups }\end{array}$ & $\begin{array}{c}\text { Number } \\
\text { of ring } \\
\text { atoms }\end{array}$ & $\begin{array}{l}\text { Q Plog } \\
\text { Pw } \\
\text { (-2 to } \\
6.5)\end{array}$ & $\begin{array}{l}\% \\
\text { Human } \\
\text { oral } \\
\text { absorption }\end{array}$ & $\mathrm{CNS}$ & $\begin{array}{l}\text { Rule } \\
\text { of } \\
\text { five }\end{array}$ \\
\hline $1 \quad \mathrm{C}_{41} \mathrm{H}_{30} \mathrm{O}_{28}$ & 970.663 & 2327.586 & 1050.003 & 17 & 29.95 & 55 & -2.557 & 1 & -2 & 3 \\
\hline $2 \mathrm{C}_{27} \mathrm{H}_{22} \mathrm{O}_{18}$ & 634.455 & 1552.483 & 778.079 & 9 & 20.55 & 28 & -1.354 & 1 & -2 & 3 \\
\hline $3 \mathrm{C}_{27} \mathrm{H}_{22} \mathrm{O}_{19}$ & 650.454 & 1671.132 & 866.924 & 7 & 20.05 & 28 & -3.007 & 1 & -2 & 3 \\
\hline $4 \mathrm{C}_{32} \mathrm{H}_{40} \mathrm{O}_{15}$ & 664.651 & 1568.806 & 821.477 & 7 & 22.45 & 17 & -1.397 & 1 & -2 & 3 \\
\hline $5 \quad \mathrm{C}_{21} \mathrm{H}_{20} \mathrm{O}_{12}$ & 464.379 & 1611.303 & 837.282 & 7 & 19.30 & 28 & 1.884 & 1 & -2 & 3 \\
\hline $6 \mathrm{C}_{27} \mathrm{H}_{30} \mathrm{O}_{16}$ & 610.521 & 2190.041 & 1057.957 & 6 & 21.30 & 34 & 0.453 & 1 & -2 & 3 \\
\hline $7 \mathrm{C}_{15} \mathrm{H}_{14} \mathrm{O}_{7}$ & 306.270 & 1519.296 & 807.567 & 10 & 10.90 & 32 & -0.515 & 1 & -2 & 3 \\
\hline $8 \mathrm{C}_{28} \mathrm{H}_{34} \mathrm{O}_{15}$ & 610.565 & 995.503 & 553.076 & 6 & 9.65 & 12 & -2.426 & 1 & -2 & 1 \\
\hline $9 \mathrm{C}_{21} \mathrm{H}_{20} \mathrm{O}_{11}$ & 448.380 & 963.976 & 535.187 & 9 & 12.35 & 6 & -1.76 & 1 & -2 & 2 \\
\hline $10 \mathrm{C}_{21} \mathrm{H}_{20} \mathrm{O}_{11}$ & 448.380 & 1127.265 & 634.363 & 7 & 13 & 20 & 0.957 & 1 & -2 & 2 \\
\hline $11 \mathrm{C}_{41} \mathrm{H}_{28} \mathrm{O}_{27}$ & 952.648 & 1094.899 & 637.616 & 5 & 7 & 12 & 2.223 & 1 & -2 & 0 \\
\hline $12 \mathrm{C}_{15} \mathrm{H}_{10} \mathrm{O}_{6}$ & 286.239 & 1443.524 & 746.044 & 6 & 9.35 & 17 & 0.427 & 2 & -2 & 1 \\
\hline $13 \mathrm{C}_{15} \mathrm{H}_{10} \mathrm{O}_{8}$ & 318.237 & 856.481 & 503.931 & 5 & 5.45 & 16 & -3.079 & 2 & -2 & 0 \\
\hline $14 \mathrm{C}_{6} \mathrm{H}_{8} \mathrm{O}_{6}$ & 176.124 & 595.353 & 369.932 & 6 & 10.20 & 0 & -1.245 & 1 & -2 & 1 \\
\hline $15 \mathrm{C}_{21} \mathrm{H}_{20} \mathrm{O}_{11}$ & 448.380 & 794.879 & 466.636 & 5 & 12.40 & 6 & 3.323 & 1 & -2 & 0 \\
\hline $16 \mathrm{C}_{15} \mathrm{H}_{10} \mathrm{O}_{6}$ & 286.239 & 1093.897 & 616.277 & 2 & 4 & 16 & 0.286 & 3 & -2 & 0 \\
\hline $17 \mathrm{C}_{7} \mathrm{H}_{6} \mathrm{O}_{5}$ & 170.120 & 834.190 & 477.400 & 5 & 5.45 & 16 & 1.289 & 2 & -2 & 0 \\
\hline $18 \mathrm{C}_{4} \mathrm{H}_{6} \mathrm{O}_{6}$ & 150.086 & 1041.592 & 547.798 & 3 & 8.10 & 15 & -0.359 & 3 & -2 & 0 \\
\hline $19 \mathrm{C}_{24} \mathrm{H}_{32} \mathrm{O}_{8}$ & 448.512 & 836.626 & 516.586 & 3 & 8.60 & 11 & 3.561 & 2 & -2 & 0 \\
\hline $20 \mathrm{C}_{7} \mathrm{H}_{12} \mathrm{O}_{6}$ & 192.167 & 1294.790 & 378.032 & 17 & 29.95 & 55 & -2.557 & 1 & -2 & 3 \\
\hline $21 \mathrm{C}_{16} \mathrm{H}_{18} \mathrm{O}_{9}$ & 354.311 & 868.249 & 578.065 & 9 & 20.55 & 28 & -1.354 & 1 & -2 & 3 \\
\hline $22 \mathrm{C}_{9} \mathrm{H}_{8} \mathrm{O}_{4}$ & 180.159 & 831.747 & 436.980 & 7 & 20.05 & 28 & -3.007 & 1 & -2 & 3 \\
\hline $23 \mathrm{C}_{21} \mathrm{H}_{20} \mathrm{O}_{10}$ & 432.381 & 878.822 & 578.603 & 7 & 22.45 & 17 & -1.397 & 1 & -2 & 3 \\
\hline $24 \mathrm{C}_{15} \mathrm{H}_{14} \mathrm{O}_{6}$ & 290.271 & 870.576 & 473.047 & 7 & 19.30 & 28 & 1.884 & 1 & -2 & 3 \\
\hline $25 \mathrm{C}_{11} \mathrm{H}_{12} \mathrm{O}_{6}$ & 280.712 & 553.076 & 668.294 & 6 & 21.30 & 34 & 0.453 & 1 & -2 & 3 \\
\hline $26 \mathrm{C}_{15} \mathrm{H}_{12} \mathrm{O}_{6}$ & 288.255 & 525.074 & 621.747 & 10 & 10.90 & 32 & -0.515 & 1 & -2 & 3 \\
\hline $27 \mathrm{C}_{10} \mathrm{H}_{10} \mathrm{O}_{4}$ & 194.186 & 643.360 & 873.822 & 6 & 9.65 & 12 & -2.426 & 1 & -2 & 1 \\
\hline $28 \mathrm{C}_{16} \mathrm{H}_{16} \mathrm{O}_{5}$ & 288.299 & 746.044 & 975.780 & 9 & 12.35 & 6 & -1.76 & 1 & -2 & 2 \\
\hline $29 \mathrm{C}_{8} \mathrm{H}_{8} \mathrm{O}_{4}$ & 168.148 & 396.249 & 780.638 & 7 & 13 & 20 & 0.957 & 1 & -2 & 2 \\
\hline $30 \mathrm{C}_{18} \mathrm{H}_{24} \mathrm{O}_{2}$ & 272.388 & 661.231 & 535.750 & 5 & 7 & 55 & 2.223 & 1 & -2 & 3 \\
\hline $31 \mathrm{C}_{15} \mathrm{H}_{14} \mathrm{O}_{3}$ & 242.274 & 456.890 & 535.178 & 6 & 9.35 & 28 & 0.427 & 2 & -2 & 3 \\
\hline $32 \mathrm{C}_{15} \mathrm{H}_{12} \mathrm{O}_{6}$ & 288.255 & 474.403 & 643.336 & 5 & 5.45 & 28 & -3.079 & 2 & -2 & 3 \\
\hline $33 \mathrm{C}_{10} \mathrm{H}_{10} \mathrm{O}_{4}$ & 194.186 & 574.897 & 673.616 & 6 & 10.20 & 17 & -1.245 & 1 & -2 & 3 \\
\hline $34 \mathrm{C}_{16} \mathrm{H}_{16} \mathrm{O}_{5}$ & 288.299 & 561.568 & 530.931 & 5 & 12.40 & 28 & 3.323 & 1 & -2 & 3 \\
\hline $35 \mathrm{C}_{8} \mathrm{H}_{8} \mathrm{O}_{4}$ & 168.148 & 578.158 & 661.271 & 2 & 4 & 34 & 0.286 & 3 & -2 & 3 \\
\hline $36 \mathrm{C}_{18} \mathrm{H}_{24} \mathrm{O}_{2}$ & 272.388 & 562.372 & 464.663 & 5 & 5.45 & 32 & 1.289 & 2 & -2 & 3 \\
\hline $37 \mathrm{C}_{24} \mathrm{H}_{32} \mathrm{O}_{7}$ & 432.513 & 673.661 & 474.700 & 3 & 8.1 & 12 & -0.359 & 3 & -2 & 1 \\
\hline $38 \mathrm{C}_{12} \mathrm{H}_{16} \mathrm{O}_{3}$ & 208.257 & 530.913 & 574.879 & 3 & 8.6 & 6 & 3.561 & 2 & -2 & 2 \\
\hline $39 \mathrm{C}_{18} \mathrm{H}_{30} \mathrm{O}_{2}$ & 278.436 & 396.932 & 578.851 & 17 & 29.95 & 20 & -2.557 & 1 & -2 & 2 \\
\hline $40 \mathrm{C}_{13} \mathrm{H}_{28} \mathrm{O}$ & 200.366 & 526.723 & 562.372 & 9 & 20.55 & 12 & -1.354 & 1 & -2 & 0 \\
\hline
\end{tabular}

SASA, solvent accessible surface area; CNS, central nervous system 

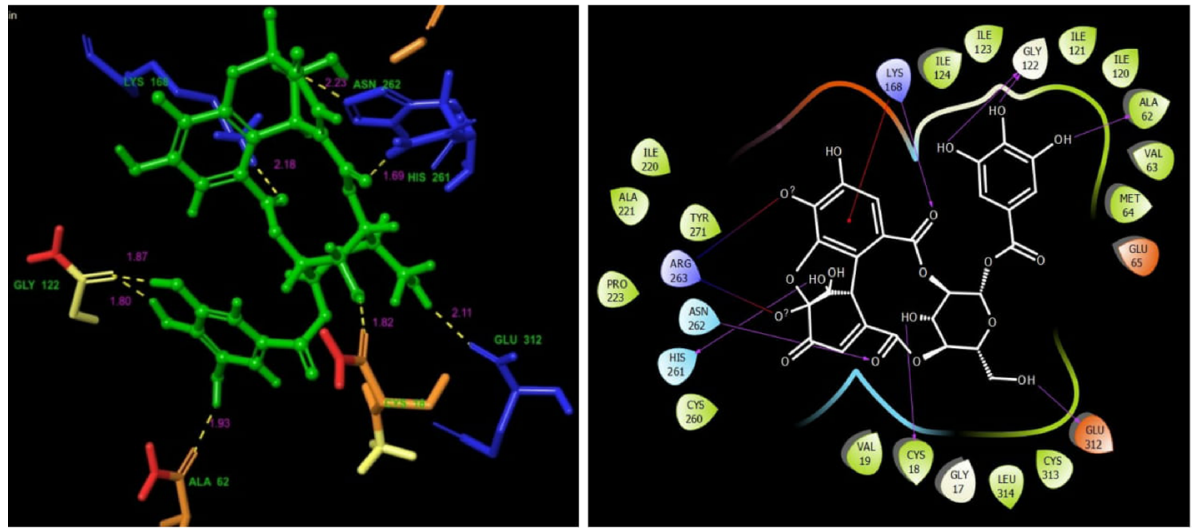

Figure 4. Residues and hydrogen bond contacts (yellow dotted line) with their distance values (pink) in furosin, at the 2D template representing the types of contacts involved between the ligand and target.

This molecule hepatoprotective value was confirmed based on their docking scores, glide energy and residues binding contacts.

\section{Nirurin}

Nirurin has the fourth valuable docking scores of -12.392 (Table 1). It also exhibited good binding affinities with target residues. This docked complex showed that there is a residue contacts between target and the nirurin. This examination showed five binding affinities such as GLU65, THR118, CYS18, HIS261 and TYR171, which are all contacts on different kinds of hydrogen bond distance values with the small molecule of nirurin. These residues contacts distance values are indicated by yellow dotted line (Figure 5). In this interaction map, the highlighted residues are all formed with hydrogen bond back bone (HB) contacts with the functional groups of ligand. Particularly, the residues HIS261 and ASN262 were contacts together in same hydroxyl groups of nirurin. As well as the residue CYS 18 is covalently bonded with ligand hydroxyl groups on separately (Figure 5). In this study, all the tested compounds contacts were shown in Table 1. Nirurin is an alkaloids nature of the phytoconstituent which is habitually present in the aerial parts of Phyllanthus niruri. Previously, the medicinal plant Phyllanthus niruri was reported against several diseases which include anti-babesial, anti-plasmodial [26], anti-hyperuricemic [27], anti-nociceptive [28], anti-HIV [29] antioxidant, hepatoprotective [30], Vasorelaxant [31] and lipid lowering [32]. It is also used to inhibit platelet aggregation [33], urolithiasis [34], hepatitis B virus, woodchuck hepatitis virus [35]. Zakaria et al. [36] reported that the copyrights to pharmaceutical provisions for treating infections caused by hepatitis B virus (US4673575), hepatitis C virus (EP1294387), adenoviruses (US20060193907) and for treating chronic inflammatory, fibrotic processes (US 6586015).

\section{Iso-quercetin}

Among the 40 molecules, iso-quercetin had the fifth
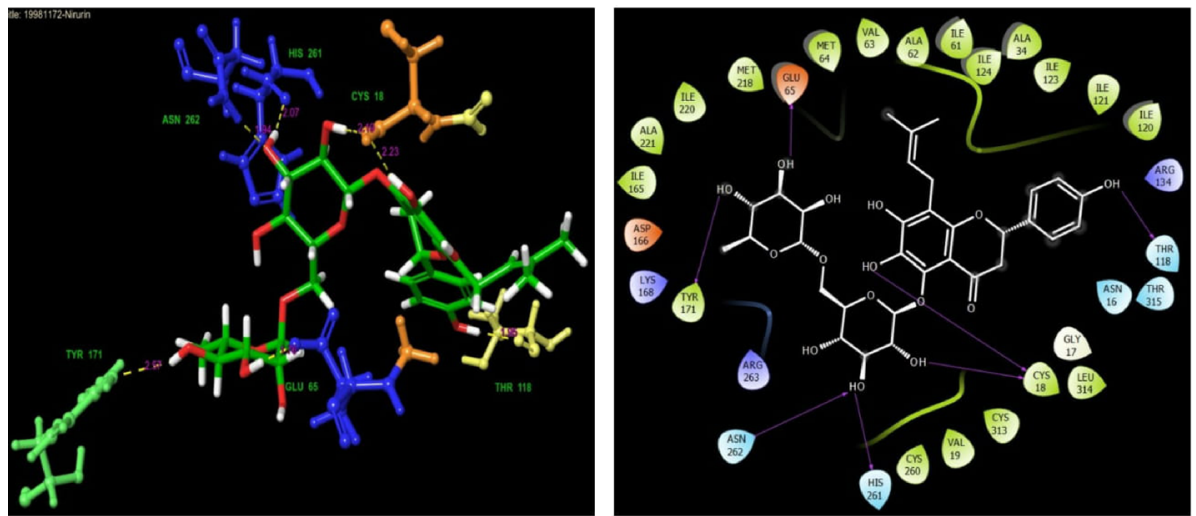

Figure 5. Residues and hydrogen bond contacts (yellow dotted line) with their distance values (pink) in nirurin, and the 2D template representing the types of contacts involved between the ligand and target. 
valuable docking scores of -11.836 , which showed good binding affinities with target (Table 1). Determination of this docked complex showed their binding affinities, such as H-bond side chain, back chain, $\pi-\pi$ stacking and salt bridge contacts. Iso-quercetin interacts with the target residues including ARG263, ALA221, GLU65, ILE124, CYS18 and HIS 261 respectively (Figure 6). For this predicted complex molecule, binding affinities was shown by means of the route of interaction map. It displayed two kinds of contacts lines like hydrogen bond backbone and $\pi-\pi$ stacking contacts. Specifically, the residues ARG263 and ALA221 formed ionic bond contacts with functional groups. CYS 4 was displayed in blue solid aero line with contacts on ligand hydroxide group (Figure 6). Iso-quercetin is a flavonoids nature of phytoconstituents which is frequently obtained from Phyllanthus emblica, P. urinaria, $P$. reticulatus, $P$. virgatus and P.muellerianus [37]. These plants were also involved in diverse range of biological actions.

\section{ADME analysis}

In this computational investigation, the physicochemical and biological properties of 40 phytoconstituents were listed in table 2. This study reveals the properties of known phytoconstituents such as molecular weight, molecular formula, volume, solvent accessible surface area, H-bond acceptor, H-bond donor, ring atoms, Q Plog, human oral absorption and central nervous system [38]. In recent scenario, the ADME related studies have been greatly helpful for the development of better drugs to globally challenging diseases and disorders.

\section{CONCLUSIONS AND FUTURE FOCUS}

The present study focused on hepatitis B virus that infects human beings due to the virus replication. At present, the conventional drugs of Hepatitis B virus induce side effects to human and few are not responsible for that diseases complication. Present computational studies found a few effective phyto-chemicals for hepatitis B virus which are identified based on their mode of interactions with hepatitis B viral protein molecule. Among the molecules, repandusinic acid has a better docking score and it was shown to good binding affinities with the target. Furthermore, the other phytochemicals such as corilagin, furosin, nirurin, iso-quercetin and gallocatechin also get better docking scores. Hence, this study concluded that the phytocompounds are a better drug candidate for hepatitis B virus. In vitro and in vivo evaluation will be essential and we hope this computational result will be helpful to proceed further with the effective drug development.

\section{MATERIALS AND METHODS}

\section{Software and hardware}

Computational analysis was carried out in Maestro v10. 2. It was complexly programmed in single software which includes ligprep, sitemap, glide grid and glide Xtra Precision. This software was installed in DELL PRECISION T1700 workstation machine which is running on Intel (R) Core (TM) i5-4590 CPU processor with 8 GB RAM and 240 GB hard disk. Centos Linux was used as the operating system [39].

\section{Biological data}

The protein molecule of hepatitis B virus $\mathrm{X}$ protein $(\mathrm{HBx})$ was retrieved from Protein data bank [40]. The target molecule data bank alpha numeric ID is $3 \mathrm{I} 7 \mathrm{H}$. Totally, 40 phytoconstituents were chosen for this docking investigation. These molecules were identified and selected with the help of previous research findings. Later, the identified
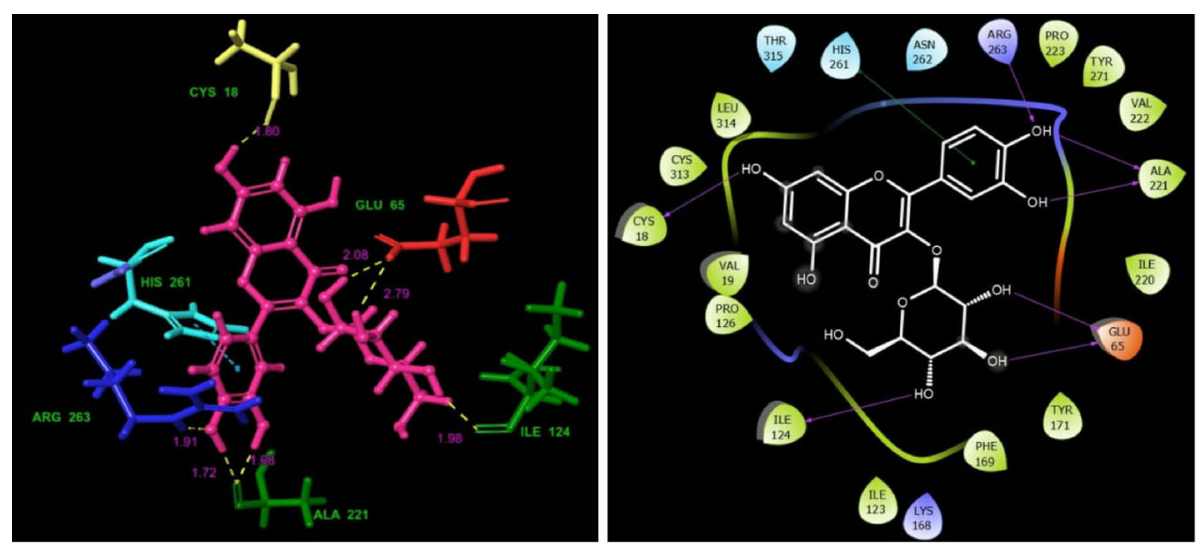

Figure 6. Residues and hydrogen bond contacts (yellow dotted line) with their distance values (pink) in iso-quercetin, and the 2D template representing the types of contacts involved in the ligand and target. 
molecules were obtained from chemical database and some were drawn in Maestro v10.2 [41].

\section{Protein preparation}

Protein preparation were made by the protein preparation wizard tool. They resolved some target harms such as the missing of side chains and the adding of back bones, and the revising of the missing residues. The x-ray crystallography structure of the target is strictly coupled with the water molecules. The water molecules occupied by protein is not qualified to acquire the docking study. Hence, through this process, we evacuated the water molecules and increased the entropy of the target. The protein preparation was followed by the method of Prabhu et al. [42].

\section{Active site validation and grid generation}

The site validation was examined by the target inner and surface regions with the help of sitemap tool in Maestro v10. 2 [43]. In the site analysis, the target showed possible active binding sites. Among them, one binding site was selected to further study based on their site values viz, site score and site area volume. Then, the selected site was used for the grid generation. Grid box shape and values were generated in $X: 5.3 ; Y: 3.71 ; Z:-20.86$ coordination. Target site was explained with $10 \AA$ radius around the ligand binding site [44].

\section{Ligand preparation}

The structures of the 40 ligand molecules were converted to 3D structure by using ligprep tool [45]. The ligands were geometrically optimized via Optimized Potentials for Liquid Simulations 2005 (OPLS2005) force field [40]. LigPrep is used in Schrodinger suite for the purpose of generating ligand of 3D structures from 1D (Smiles) and 2D (SDF) representation, probing for tautomers and steric isomers and geometry minimization of ligands [46,47].

\section{Molecular docking}

The molecular docking study was used to perform Xtra precision docking mode in our study. It was used for predicting the binding affinities of target to ligand, ligand efficiency, and ligand inhibitory constant to the target. The complex of thirty nine ligands was docked with the active site of the target by using Glide Xtra precision (XP) which docks ligands $[44,48]$

\section{ADMET analysis}

This analysis was carried out by QuikProp tool in Masetro v10.2. All the ligand molecules were analyzed with the parameters like hydrogen bond donor, hydrogen bond acceptor, blood brain barrier, central nervous system followed by Vijayakumar et al. [2], and Morvin et al. [49]

\section{ACKNOWLEDGEMENTS}

The authors are grateful to the DST-SERB (SB/YS/LS-109/2014) for providing financial assistance with this project. We especially express our thanks to the management of A.V.V.M. Sri Pushpam College (Autonomous), Poondi, for providing the necessary facilities and support to this work.

\section{COMPLIANCE WITH ETHICS GUIDELINES}

The authors Vijayakumar Subramaniyan, Reetha Sekar, Arulmozhi Praveenkumar and Rajalakshmi Selvam declare that they have no conflict of interests.

All procedures performed in studies were in accordance with the ethical standards of the institutional and/or national research committee and with the 1964 Helsinki declaration and its later amendments or comparable ethical standards.

\section{REFERENCES}

1. Balavignesh, V., Srinivasan, E., Ramesh Babu, N.G. and Saravanan, N. (2013) Molecular docking study ON NS5B polymerase of hepatitis $\mathrm{C}$ virus by screening of volatile compounds from Acacia concinna and ADMET prediction. Int. J. Pharm. Life Sci. 4, 2548-2558

2. Vijayakumar, S., Harikrishnan, J. P., Prabhu, S., Morvin Yabesh, J. E. and Manogar, P. (2016) Quantitative ethnobotanical survey of traditional siddha medical practitioners from thiruvarur district with hepatoprotective potentials through in silico methods, Achieve. Life Sci., 10, 11-26

3. Balavignesh, V., Srinivasan, E., Ramesh Babu, N. G. and Saravanan, N. (2013) Molecular docking study ON NS5B polymerase of hepatitis $\mathrm{C}$ virus by screening of volatile compounds from Acacia concinna and ADMET prediction. Int. J. Pharma. Life Sci., 4, 2548-2558

4. Yang, S., Xing, H., Wang, Q., Wang, X., Liu, S. and Cheng, J. (2016) De novo entecavir + adefovir dipivoxil + lamivudine triple-resistance mutations resulting from sequential therapy with adefovir dipivoxil, and lamivudine. Ann. Clin. Microbiol. Antimicrob., 15, 24

5. Zhang, J., Ratanasirintrawoot, S., Chandrasekaran, S., Wu, Z., Ficarro, S. B., Yu, C., Ross, C. A., Cacchiarelli, D., Xia, Q., Seligson, M., et al. (2016) LIN28 regulates stem cell metabolism and conversion to primed pluripotency. Cell Stem Cell, 19, 6680

6. Sitterlin, D., Lee, T. H., Prigent, S., Tiollais, P., Butel, J. S. and Transy, C. (1997) Interaction of the UV-damaged DNA-binding protein with hepatitis $\mathrm{B}$ virus $\mathrm{X}$ protein is conserved among mammalian hepadnaviruses and restricted to transactivation- 
proficient X-insertion mutants. J. Virol., 71, 6194-6199

7. Chen, H. S., Kaneko, S., Girones, R., Anderson, R. W., Hornbuckle, W. E., Tennant, B. C., Cote, P. J., Gerin, J. L., Purcell, R. H. and Miller, R. H. (1993) The woodchuck hepatitis virus $\mathrm{X}$ gene is important for establishment of virus infection in woodchucks. J. Virol., 67, 1218-1226

8. Bergametti, F., Bianchi, J. and Transy, C. (2002) Interaction of hepatitis $\mathrm{B}$ virus $\mathrm{X}$ protein with damaged DNA-binding protein p127: structural analysis and identification of antagonists. J. Biomed. Sci., 9, 706-715

9. Iftikhar, H., Batool, S., Deep, A., Narasimhan, B., Sharma, P. C. and Malhotra, M. (2017) In silico analysis of the inhibitory activities of GABA derivatives on 4-aminobutyrate transaminase. Arab. J. Chem., 10, S1267-S1275

10. Velmurugan, V. and Arunachalam, G. (2014) Comparative molecular docking study of rutin against GABA A type receptor and 4-aminobutyrate-aminotransferase for anti-convulsant activity. J. Chem. Pharm. Res., 9, 974-978

11. Yunta, M. J. R. (2016) Docking and ligand binding affinity: uses and pitfalls. Ame. J. Model Optimiz., 3, 74-114

12. Jordan, T. C., Burnett, S. H., Carson, S., Caruso, S. M., Clase, K., DeJong, R. J., Dennehy, J. J., Denver, D. R., Dunbar, D., Elgin, S. C., et al. (2014) A broadly implementable research course in phage discovery and genomics for first-year undergraduate students. MBio, 5, e01051-e13

13. Patschull, A. O., Gooptu, B., Ashford, P., Daviter, T. and Nobeli, I. (2012) In silico assessment of potential druggable pockets on the surface of $\alpha 1$-antitrypsin conformers. PLoS One, 7, e36612

14. Mouhssen, L. (2014) Methods to study the phytochemistry and bioactivity of essential oils. Phyto. Res., 18, 35-448

15. Taylor, L. (2000) Plant Based Drugs and Medicines. Raintree Nutrition Inc., Carson City, 89701

16. Moreira, J., Klein-Júnior, L. C., Filho, V. C. and de Campos Buzzi, F. (2013) Anti-hyperalgesic activity of corilagin, a tannin isolated from Phyllanthus niruri L. (Euphorbiaceae). J. Ethnopharmacol., 146, 318-323

17. Duan, W., Yu, Y. and Zhang, L. (2005) Antiatherogenic effects of phyllanthus emblica associated with corilagin and its analogue. Yakugaku Zasshi, 125, 587-591

18. Chen, Y., Zhang, J., Li, C., Chen, Z. and Jia, L. (2012) Extraction and in vitro antioxidant activity of mopan persimmon polysaccharide. J. Appl. Polym. Sci., 124, 1751-1756

19. Kinoshita, S., Inoue, Y., Nakama, S., Ichiba, T. and Aniya, Y. (2007) Antioxidant and hepatoprotective actions of medicinal herb, Terminalia catappa L. from Okinawa Island and its tannin corilagin. Phytomedicine, 14, 755-762

20. Hau, D. K., Zhu, G. Y., Leung, A. K., Wong, R. S., Cheng, G. Y., Lai, P. B., Tong, S. W., Lau, F. Y., Chan, K. W., Wong, W. Y., et al. (2010) In vivo anti-tumour activity of corilagin on Hep3B hepatocellular carcinoma. Phytomedicine, 18, 11-15

21. Zhang, Y. J., Abe, T., Tanaka, T., Yang, C. R. and Kouno, I. (2001) Phyllanemblinins A-F, new ellagitannins from Phyllanthus emblica. J. Nat. Prod., 64, 1527-1532

22. Kumaran, A. and Karunakaran, R. J. (2006) Nitric oxide radical scavenging active components from Phyllanthus emblica L. Plant Foods Hum. Nutr., 61, 1-5

23. Huang, Y. L., Chen, C. C., Hsu, F. L. and Chen, C. F. (1998) Tannins, flavonol sulfonates, and a norlignan from Phyllanthus virgatus. J. Nat. Prod., 61, 1194-1197

24. Miguel, O., Calixto, J., Santos, A., Messana, I., Ferrari, F., Filho, V., Pizzolatti, M. and Yunes, R. (1996) Chemical and preliminary analgesic evaluation of geraniin and furosin isolated from Phyllanthus sellowianus. Planta Med., 62, 146-149

25. Agyare, C., Lechtenberg, M., Deters, A., Petereit, F. and Hensel, A. (2011) Ellagitannins from Phyllanthus muellerianus (Kuntze) Exell.: Geraniin and furosin stimulate cellular activity, differentiation and collagen synthesis of human skin keratinocytes and dermal fibroblasts. Phytomedicine, 18, 617-624

26. Subeki, S., Matsuura, H., Takahashi, K., Yamasaki, M., Yamato, O., Maede, Y., Katakura, K., Kobayashi, S., Trimurningsih, T., Chairul, C., et al. (2005) Anti-babesial and anti-plasmodial compounds from Phyllanthus niruri. J. Nat. Prod., 68, 537-539

27. Murugaiyah, V. and Chan, K. L. (2009) Mechanisms of antihyperuricemic effect of Phyllanthus niruri and its lignan constituents. J. Ethnopharmacol., 124, 233-239

28. Santos, A. R. S., Filho, V. C., Yunes, R. A. and Calixto, J. B. (1995) Further-studies on the antinociceptive action of the hydroalcoholic extracts from plants of the genus Phyllanthus. J. Pharm. Pharmacol., 47, 66-71

29. Naik, A. D. and Juvekar, A. R. (2003) Effects of alkaloidal extract of Phyllanthus niruri on HIV replication. Ind. J. Med. Sci., 57, 387-393

30. Chatterjee, M. and Sil, P. C. (2006) Hepatoprotective effect of aqueous extract of Phyllanthus niruri on nimesulide-induced oxidative stress in vivo. Ind. J. Biochem. Biophys., 43, 299-305

31. Iizuka, T., Moriyama, H. and Nagai, M. (2006) Vasorelaxant effects of methyl brevifolincarboxylate from the leaves of Phyllanthus niruri. Biol. Pharm. Bull., 29, 177-179

32. Dhingra, D., Sharma, A. (2006) Antidepressant-like activity of nhexane extract of nutmeg (Myristica fragrans) seeds in mice. J. Med. Food. 9, 84-92

33. Venkateswaran, P. S., Millman, I. and Blumberg, B. S. (1987) Effects of an extract from Phyllanthus niruri on hepatitis B and woodchuck hepatitis viruses: in vitro and in vivo studies. Proc. Natl. Acad. Sci. USA, 84, 274-278

34. Zakaria, M. K., Sankhyan, A., Ali, A., Fatima, K. and Azhar, A. (2014) HBV/HCV infection and inflammation. J. Genet. Syndr. Gene Ther., 5, 241.

35. Li, Y., Yao, J., Han, C., Yang, J., Chaudhry, M. T., Wang, S., Liu, H. and Yin, Y. (2016) Quercetin, inflammation and immunity. Nutrients, 8, 167

36. Yao, Q. Q. and Zuo, C. X. (1993) Chemical studies on the constituents of Phyllanthus urinaria L. ACTA Pharm. Sin. B, 28, 829-835

37. Iizuka, T., Nagai, M., Taniguchi, A., Moriyama, H., Hoshi, K. (2005) 125th Annual Meeting of the Pharmaceutical Society of Japan, pp. 134. Tokyo

38. Vijayakumar, S., Manogar, P., Prabhu, S., Pugazhenthi, M. and 
Praseetha, P. K. (2019) A pharmacoinformatic approach on cannabinoid receptor 2 (CB2) and different small molecules: Homology modelling, molecular docking, MD simulations, drug designing and ADME analysis. Comput. Biol. Chem., 78, 95107

39. Schrödinger, LLC, New York, 2016

40. Arulmozhi, P., Vijayakumar, S., Praseetha, P. K. and Jayanthi, S. (2019) Extraction methods and computatioinal approaches for evaluation of antimicrobial compounds from Capparis zylanica L. Anal. Biochem., 572, 33-44

41. Vijayakumar, S., Sathiya, M., Arulmozhi, P., Prabhu, S., Manogar, P., Vinothkannan, R. and Parameswari, N. (2018) Molecular docking and ADME properties of bioactive molecules against human acid-betaglucosidase enzyme, cause of Gaucher's disease. In silico Pharmacology, 6, 1-11

42. Prabhu, S., Vijayakumar, S., Manogar, P., Maniam, G. P. and Govindan, N. (2017) Homology modeling and molecular docking studies on type II diabetes complications reduced PPAR $\gamma$ receptor with various ligand molecules. Biomed. Pharmacother., 92, 528535

43. SiteMap version 2.3, Schrödinger, LLC, New York, 2016

44. Glide, 2011, version 5.7, Schrödinger, LLC, New York, 2016

45. Prime version 3.7, Schrödinger, LLC, New York, 2016

46. LigPrep. 2011, Version 2.5, Schrödinger, LLC, NewYork, 2016

47. Mahapatra, R. K., Behera, N. and Naik, P. K. (2012) Molecular modeling and prediction of binding mode and relative binding affinity of Art-Qui-OH with P. falciparum Histo-Aspartic Protease (HAP). Bioinformation, 8, 827-833

48. QikProp. 2011, version 2.3, Schrödinger, LLC, NewYork, 2016

49. Morvin Yabesh, J. E., Vijayakumar, S., Arulmozhi, P., Mahadevan, S. and Manogar, P. (2017) Molecular Docking, ADMET Analysis and Dynamics Approach to Potent Natural Inhibitors against Sex Hormone Binding Globulin in Male Infertility. Pharmacogn. J., 6, 35-43 